\title{
WEED SUPPRESSION IN MAIZE (ZEA MAYS L.) THROUGH THE ALLELOPATHIC EFFECTS OF SORGHUM [SORGHUM BICOLOR (L.) CONARD MOENCH.] SUNFLOWER (HELIANTHUS ANNUUS L.) AND PARTHENIUM (PARTHENIUM HYSTEROPHORUS L.) PLANTS
}

\author{
RASHID, H. U. ${ }^{1}-$ KHAN, A. ${ }^{1}-$ HASSAN, G. ${ }^{2}-$ KHAN, S. U. ${ }^{1}-$ SAEED, M. ${ }^{3}-$ KHAN, S. A. ${ }^{4}-$ \\ KHAN, S. M. ${ }^{5}-$ HASHIM, S. ${ }^{2}$ \\ ${ }^{I}$ Department of Agronomy, The University of Haripur, Haripur, Pakistan \\ ${ }^{2}$ Department of Weed Science, The University of Agriculture Peshawar, Peshawar, Pakistan \\ ${ }^{3}$ Department of Agriculture, The University of Swabi, Swabi, Pakistan \\ ${ }^{4}$ Department of PBG, The University of Haripur, Haripur, Pakistan \\ ${ }^{5}$ Department of Horticulture, The University of Haripur, Haripur, Pakistan \\ *Corresponding author \\ e-mail:peerayub@gmail.com
}

(Received $19^{\text {th }}$ Jan 2020; accepted $25^{\text {th }}$ May 2020)

\begin{abstract}
The present study was carried out at the Weed Science Research Laboratory, The University of Agriculture, Peshawar Pakistan (June-July 2013 and Sep-Oct 2013). To evaluate the most effective and economical treatment for weed management in maize (Zea mays L.), the pot experiment was performed using completely randomized design (CRD) with three replications. Allelopathic effects of Sorghum bicolor (L.) Conard Moench., Helianthus annuus L., Parthenium hysterophorus L, and the commercial herbicide (atrazine @ $18 \mathrm{~g} \mathrm{~L}^{-1}$ ) was used for comparison. The data were recorded on germination and seedling growth of test species (Zea mays, Trianthema portulacastrum and Lolium rigidum). The data showed that S. bicolor $+H$. annuus + P. hysterophorus water extract (WE) @ $33.33+33.33+33.33$ (g $\mathrm{L}^{-1}$ ) reduced dry biomass of $T$. portulacastrum and $L$. rigidum by 35 and $41 \%$ respectively, whereas the commercial herbicide by $45-47 \%$. Maize seeds were found more tolerant than the weed species tested. Hence, it is concluded that extracts applied in mutual combination had more inhibitory effect than their sole applications, however, the efficacy of atrazine was more effective in suppressing germination and seedling growth of the tested species. The degree of toxicity for the various treatments can be placed in the following array of inhibition: Herbicide > combined extracts > isolated extracts. The current study showed that all the tested allelopathic plants contain water soluble allelochemicals which could inhibit/retard the germination percentage and seedling growth of the tested species. Hence, the findings of the current study suggest that it is possible to use these extracts as an alternative to synthetic herbicide (s) for sustainable weed management in maize. However, further studies are suggested to confirm our findings under field conditions.
\end{abstract}

Keywords: allelochemicals, atrazine, water extracts, weed management

\section{Introduction}

Weed infestation is and has been a major constraint in maize production systems and is reported to reduce its yield by 24-83\% (Dogan et al., 2004; Usman et al., 2001). Weeds are the most ever-present class of pests that interfere with crop plants through allelopathy and competition for nutrients, moisture, solar radiation, gases and space resulting in direct loss to quantity and quality of the product (Gupta, 2004). The yield of 
maize could be reduced up to $32 \%$ due to horse purslane (Trianthema portulacastrum) infestation (Balyan and Bhan, 1989) and up to $80 \%$ due to the competition with rigid ryegrass (Lolium rigidum) depending on the season and infestation level (Izquierdo et al., 2003). The worst weeds competitive with Zea mays L. in Pakistan are purple nutsedge (Cyprus rotundus L.), horse purslane (Trianthema portulacastrum L.), bermuda grass (Cynodon dactylon (L.) Pers., common lambasquarters (Chenopodium album L.), barnyard grass (Echinochloa crus-galli L. Beauv.) and jungle rice (E. colona (L.) Link) (Muhammad et al., 2009). The predominance and competitive ability of weeds with maize or corn varies due to the geographical location, competitive ability of the variety planted, nutrients availability, availability of moisture, soil type and soil management. In the US there is a variation in weed flora from state to state, but the commonly predominant weeds include common waterhemp (Amaranthus tuberculatus), giant ragweed (Ambrosia trifida), horseweed (marestail) (Conyza canadensis) and velvetleaf (Abutilon theophrasti) (NewGenFarmer Maize + Soybean, 2020). In South Africa, common lambsquarters (Chenopodium album), purple nutsedge (Cyperus rotundus), yellow nutsedge (Cyperus esculentus) and bermuda grass (Cynodon dactlon) are ranked as the worst competitors of maize (University of Pretoria, 2020).

Weed control emerged an easy job due to the advent of 2.4-D and its analogs during the second world war era in the early 1940's. It was followed by the discovery of myriads of herbicides with varying modes of action and specificity on weeds. But this panacea started dwindling after the discovery of resistance to diclofop in Oregon state USA in the early 1980s'. Ironically the list of resistant weeds has kept growing to different herbicides and presently 512 unique cases (species $\mathrm{x}$ site of action) of herbicide resistant weeds, with 262 species (152 dicots and 110 monocots) have been reported globally in 93 crops in 70 countries (Heap, 2020). The non-judicious use of herbicides can create many environmental and health related problems everywhere in addition to resistance development in weeds (Jabran et al., 2008; Khan et al., 2010). Recently thirty-eight weed species have now evolved resistance to glyphosate, spread across 37 countries of the world infesting 34 different crops and six non-crop situations (Heap and Duke, 2018), which includes some of the worst weeds of the world. Hence, principal reliance on herbicides has become obscure and alternate weed control measures are indispensable. Hand weeding is labor intensive, time consuming and getting more expensive, hence mostly impracticable. Cultural methods are environment friendly, but very slow in action. Therefore, scientists realized that the alternative to herbicides should be designed for sustainable weed management by the use of allelopathic crop plants and weeds for quality production of crops and to reduce the use of synthetic herbicides to contribute to maintaining sustainable agriculture (An et al., 2005; Jabran et al., 2007, 2015; Khan et al., 2012; Hassan et al., 2018).

Several allelopathic plant species have been reported for weed management in cereal crops through the inhibitory effect on weed species. Allelopathy is a new approach to be used as an alternative to synthetic herbicides for the weed management as a source of bio herbicides. Several allelopathic plant species such as Sorghum bicolor (L.) Conard Moench. (Cheema and Khaliq, 2003; Weston and Duke, 2003), Halianthus annuus L. (Leather, 1987; Batish et al., 2002) and Parthenium hysterophorus L. (Adkins et al., 1996; Belz et al., 2007; Belz, 2016; Hassan et al., 2018) are inhibitory at high doses as well as stimulatory to weeds at low doses due to hormesis (Belz, 2008).

Keeping in view the importance of these allelopathic plants on weeds, the present study was designed with the objective to identify the most effective water extracts of 
allelopathic species applied isolated and in mixture for control of weeds in maize under Laboratory (pot conditions).

\section{Materials and methods}

Laboratory based Pot experiments were conducted at the Weed Research Laboratory, The University of Agriculture Peshawar, Pakistan during June-July 2013 and subsequently repeated in September-October 2013.

\section{Collection of allelopathic plants}

Sorghum [Sorghum bicolor (L.) Conard Moench.] and sunflower (Helianthus annuus L.) were collected from the farmers' fields in district Swabi, Pakistan while, parthenium (Parthenium hesterophorus L.) plants were collected from the roadsides and waste areas of Swabi. Sorghum and sunflower were collected after harvesting the crops in the field while parthenium was collected freshly at maturity stage. All the plant samples were cleaned to remove dust and other particles and then were dried in oven (Kenton; KH120AS) for $72 \mathrm{~h}$ at $65^{\circ} \mathrm{C}$ and were ground with the help of an electrical grinder. The grinded samples of all the three species were kept in bags and labeled properly for further use in both runs of experiments.

\section{Preparation of water extracts}

All the plants' powders were mixed with each other and with distilled water as the treatment specifications @ 1:10 (w/v). The extracts were kept at room temperature $20 \pm 22^{\circ} \mathrm{C}$ for $48 \mathrm{~h}$ and filtered through muslin cloth and finally through Whatman No.1 filter paper to collect the respective water extract. Synthetic herbicide (atrazine) and distilled water was included as check. Fungicide Topsin-M 70\% @ $2 \mathrm{~g} \mathrm{~kg}^{-1}$ was used in all treatments in order to avoid fungal infestation. Water extracts bottles were individually tagged and stored for further utilization.

\section{Experimental details}

A total of 81 plastic pots $(12 \mathrm{~cm}$ height and $15 \mathrm{~cm}$ diameter) were filled with $1 \mathrm{~kg}$ of soil. The soil samples were analyzed for soil physicochemical properties. The soil was sandy loam in texture with almost neutral soil reaction, low in organic matter, nitrogen and phosphorus content (Table 1). The details of treatments are presented in Table 2. Each treatment was replicated three times. All the seeds of the tested species were soaked in their respective treatments for $48 \mathrm{~h}$ and were sown in the pots. There were 10 seeds of each species per pot. All the pots were irrigated with a mini sprayer when needed. After recording all the required data, the experiment was terminated after 45 days. The experiment was laid out in completely randomized design (CRD) and the treatment means were separated by Least Significant Difference Test (LSD) at $\mathrm{P}=0.05$.

\section{Data recording}

Germination (\%) was recorded by counting the number of germinated seeds in each Pot and percentages were computed and recorded for each treatment. Seeds having 2 $\mathrm{mm}$ radicle were considered as germinated. On a daily basis germination\% were recorded and days to $50 \%$ germination were counted for each treatment. After 
germination, shoot length $(\mathrm{cm})$ was measured with a measuring scale for all the germinated seedlings in each treatment. Dry biomass $(\mathrm{g})$ was measured on an electrical balance after drying the fresh biomass in an oven at $65^{\circ} \mathrm{C}$ for $48 \mathrm{~h}$. The data presented for the experiment are the pooled data of two runs since the runs were not significantly different statistically $(\mathrm{P}>0.05)$. Experiments were discarded after 45 days data for shoot length, fresh and dry biomass were recorded.

Table 1. Physicochemical properties of the soil used in the experiment

\begin{tabular}{c|c}
\hline Soil parameters & Tillage depths (0-30 cm) \\
\hline Textural class & Silt Loam \\
Clay (\%) & 15.13 \\
Silt (\%) & 60.7 \\
Sand (\%) & 21.8 \\
$p \mathrm{H}$ & 7.63 \\
EC (d Sm-1) & 0.06 \\
Organic matter (\%) & 0.71 \\
Total N (\%) & 0.028 \\
Available P (mg kg ${ }^{-1}$ soil) & 4.17 \\
Extractable K (mg kg soil $)^{-1}$ & 105 \\
\hline
\end{tabular}

Table 2. Treatment details of the experiment

\begin{tabular}{|c|c|c|}
\hline \multicolumn{3}{|c|}{ Factor A. Treatments (plant water extracts) } \\
\hline Treatments & Water extracts Wes species & Wes conc. $\mathrm{g} \mathrm{L}^{-1}(\mathrm{w} / \mathrm{v})$ \\
\hline 1 & Sorghum & 100 \\
\hline 2 & Sunflower & 100 \\
\hline 3 & Parthenium & 100 \\
\hline 4 & Sorghum + Sunflower & $50+50$ \\
\hline 5 & Sorghum + Parthenium & $50+50$ \\
\hline 6 & Sunflower + Parthenium & $50+50$ \\
\hline 7 & Sorghum + Sunflower + Parthenium & $33.3+33.3+33.3$ \\
\hline 8 & Atrazine (herbicide) & 18 \\
\hline 9 & Control (Distilled water) & - \\
\hline \multicolumn{3}{|c|}{ Factor B. Test species } \\
\hline 1 & \multirow{3}{*}{\multicolumn{2}{|c|}{$\begin{array}{c}\text { Maize (Zea mays L.). } \\
\text { Trianthema partulacastrum L. (horse purslane) } \\
\text { Lolium rigidum } \text { L. (rigid ryegrass) }\end{array}$}} \\
\hline 2 & & \\
\hline 3 & & \\
\hline
\end{tabular}

\section{Statistical analysis}

The data recorded for all the individual parameters were statistically analyzed using the appropriate ANOVA suitable for Completely Randomized Design (CRD). Means were separated by using LSD test at $\mathrm{P} \leq 0.05$ (Steel et al., 1997). The statistical Software Statistic 8.1 was used for statistical calculations. 


\section{Results and discussion}

\section{Germination (\%)}

The statistical analysis of the data revealed that various plant extract treatments had significant effect on germination (\%) of the tested species (Table 3). The data recorded showed the maximum germination $(100 \%)$ of maize in control (distilled water) treatment, while the minimum germination $(85 \%)$ was recorded at sunflower + parthenium (WEs), similarly for horse purslane seeds maximum germination $(75 \%)$ was recorded in the control (distilled water) treatment while the minimum germination $(36.67 \%)$ was recorded in herbicide (atrazine) treatment. Furthermore, data recorded for rigid ryegrass showing maximum germination (98.33\%) was observed in control (distilled water) treatment while the minimum (40\%) was equally recorded in herbicide (atrazine) and sunflower + sorghum + parthenium (WEs) treatments. Among the species means the highest germination $(90.55 \%)$ was recorded in control (distilled water) treatment followed by rigid ryegrass $(57.59 \%)$, whereas the lowest value $(49.81 \%)$ was recorded for horse purslane. Among the treatment means, the highest value of germination $(83.89 \%)$ was recorded in control (distilled water) treatment, while the lowest value $(55.56 \%)$ was recorded in herbicide (atrazine) treatment followed by sunflower + sorghum + parthenium (WEs) $(56.11 \%)($ Table 3).

Table 3. Allelopathic effect of different plants water extracts applied isolated and in combination on germination (\%) of Z. mays, and its associated weeds under laboratory conditions (pots study

\begin{tabular}{|c|c|c|c|c|}
\hline \multirow{2}{*}{ Treatments $(1: 10$ w/v $)$} & \multicolumn{3}{|c|}{ Species tested } & \multirow{2}{*}{$\begin{array}{c}\text { Extracts } \\
\text { means }\end{array}$} \\
\hline & Z. mays & T. partulacastrum & L. rigidum & \\
\hline Sorghum & $90.0 \mathrm{bc}$ & $56.7 \mathrm{fg}$ & $78.3 \mathrm{~d}$ & $75.0 \mathrm{~b}$ \\
\hline Sunflower & $86.67 \mathrm{bc}$ & $56.7 \mathrm{fg}$ & $73.33 \mathrm{de}$ & $72.2 b$ \\
\hline Parthenium & $91.67 \mathrm{~b}$ & $58.33 \mathrm{f}$ & $71.67 \mathrm{e}$ & $73.9 b$ \\
\hline Sorghum + Sunflower (50\% ea.) & $86.67 \mathrm{bc}$ & $45.00 \mathrm{ij}$ & $51.67 \mathrm{gh}$ & $61.1 b c$ \\
\hline Sorghum + Parthenium (50\% ea.) & $86.67 \mathrm{bc}$ & $48.33 \mathrm{hi}$ & $51.67 \mathrm{gh}$ & $62.3 \mathrm{bc}$ \\
\hline Sunflower + Parthenium (50\% ea.) & $85.00 \mathrm{c}$ & $50.00 \mathrm{hi}$ & $53.33 \mathrm{fgh}$ & $62.8 \mathrm{c}$ \\
\hline $\begin{array}{c}\text { Sunflower }+ \text { Sorghum }+ \text { Parthenium } \\
\text { (33.3\%ea.) }\end{array}$ & $88.33 \mathrm{bc}$ & $40.00 \mathrm{jk}$ & $40.00 \mathrm{jk}$ & $56.1 \mathrm{~d}$ \\
\hline Atrazine (herbicide) & $86.67 \mathrm{bc}$ & $36.67 \mathrm{k}$ & $40.00 \mathrm{jk}$ & $54.5 \mathrm{ad}$ \\
\hline Control (distilled water) & $100.00 \mathrm{a}$ & $75.00 \mathrm{de}$ & $98.33 \mathrm{a}$ & $91.1 \mathrm{a}$ \\
\hline Test species means & $89.07 \mathrm{a}$ & $51.85 \mathrm{c}$ & $62.03 \mathrm{~b}$ & \\
\hline
\end{tabular}

$\mathrm{LSD}_{0.05}$ for extracts $=3.51$, for test species $=2.92$ and for interaction $=6.07$ and the means followed by the same letter (s) in the respective category do not differ from one another at $\mathrm{P} \leq 0.05$ according to $\mathrm{LSD}_{0.05}$ test

Overall encouraging results of these extracts indicate the presence of germination inhibitors in the allelochemicals released by these plant species. Leather (1983) reported that Chlorogenic acid and Iso-chlorogenic acids could reduce the seed germination of many weed species. Guenzi and McCalla (1966) isolated and identified chlorogenic acid in Sorghum bicolor along with other phenolic acids; similarly, Anjum et al. (2005) isolated and identified chlorogenic acid and iso-chlorogenic acid in sunflower. Therefore, the current study suggests that these extracts could be further explored for sustainable weed management in maize under ambient field condition. 


\section{Days to $50 \%$ germination}

The statistical analysis of the data revealed that the water extracts had significant effect on days to $50 \%$ germination of the tested species (Table 4). Maximum days to $50 \%$ germination (5 days) were equally recorded for sorghum + parthenium (WEs), sunflower + parthenium (WEs) and herbicide (atrazine) treatments which were statistically at par with the rest of the treatments, while minimum (3 days) was recorded for control (distilled water) treatment. Furthermore, for horse purslane the maximum (8.83 days) days to germination was recorded in sorghum + sunflowers + parthenium (WEs) treatment which was statistically at par with herbicide (atrazine), sorghum + sunflower (WEs), and sorghum + parthenium (WEs) treatments while the minimum days to $50 \%$ germination (4.50 days) was recorded in control (distilled water) treatment. Similarly, for rigid ryegrass, the maximum value (6.83 days) was recorded in herbicide (atrazine) treatment which was statistically at par with sunflower + sorghum + parthenium (WEs) treatment, while the minimum value (3 days) were recorded in control (distilled water) treatment. Among the species, means maximum days to $50 \%$ germination (7.55 days) were recorded for Trianthema portulacstrum (horse purslane) followed by Lolium rigidum (rigid ryegrass) (5.22 days), whereas the minimum (4.59 days) were recorded in maize. Among the treatment means, maximum (6.83 days) time was recorded in herbicide (atrazine) treatment whereas the minimum (3.50 days) was recorded in control (distilled water) treatment.

Table 4. Allelopathic effect of different plants water extracts applied isolated and in combination on days to $50 \%$ germination of Z. mays, and its associated weeds under laboratory conditions (pots study)

\begin{tabular}{|c|c|c|c|c|}
\hline \multirow{2}{*}{ Treatments $(1: 10 \mathrm{w} / \mathrm{v})$} & \multicolumn{3}{|c|}{ Species tested } & \multirow{2}{*}{$\begin{array}{c}\text { Extracts } \\
\text { means }\end{array}$} \\
\hline & Z. mays & T. partulacastrum & L. rigidum & \\
\hline Sorghum & $4.50 \mathrm{ijk}$ & $6.33 \mathrm{cde}$ & $4.67 \mathrm{ij}$ & $5.17 \mathrm{~d}$ \\
\hline Sunflower & $4.83 \mathrm{ij}$ & $6.00 \mathrm{efg}$ & $4.00 \mathrm{k}$ & $4.94 \mathrm{~d}$ \\
\hline Parthenium & $4.33 \mathrm{jk}$ & $6.67 \mathrm{~cd}$ & $4.50 \mathrm{ijk}$ & $5.17 \mathrm{~d}$ \\
\hline Sorghum + Sunflower (50\% ea.) & $4.83 \mathrm{ij}$ & $8.67 \mathrm{a}$ & $6.17 \mathrm{def}$ & $6.56 \mathrm{ab}$ \\
\hline Sorghum + Parthenium (50\% ea.) & $5.00 \mathrm{hi}$ & $8.50 \mathrm{a}$ & $5.67 f g$ & $6.39 b$ \\
\hline Sunflower + Parthenium (50\% ea.) & 5.00hi & $7.33 \mathrm{~b}$ & $5.50 \mathrm{gh}$ & $5.94 c$ \\
\hline Sunflower + Sorghum + Parthenium (33.3\%ea.) & $4.83 \mathrm{ij}$ & $8.83 \mathrm{a}$ & $6.67 \mathrm{~cd}$ & $6.78 \mathrm{a}$ \\
\hline Atrazine (herbicide) & $5.00 \mathrm{hi}$ & $8.67 \mathrm{a}$ & $6.83 b c$ & $6.83 \mathrm{a}$ \\
\hline Control (distilled water) & 3.001 & $4.50 \mathrm{ijk}$ & 3.001 & $3.50 \mathrm{e}$ \\
\hline Test species means & $4.59 \mathrm{a}$ & $7.55 b$ & $5.22 \mathrm{a}$ & \\
\hline
\end{tabular}

$\mathrm{LSD}_{0.05}$ for extracts $=0.38$, for test species $=0.22$ and for interaction $=0.66$ and the means followed by the same letter ( $\mathrm{s}$ ) in the respective category do not differ from one another at $\mathrm{P} \leq 0.05$ according to $\mathrm{LSD}_{0.05}$ test

Our findings are in line with the findings of Babar et al. (2009), who concluded that chickpea seeds soaked in root extract of Asphodelus tenuifolius Cav. took more time for germination. Guenzi and McCalla (1966) reported that the presence of chlorogenic acid along with other responsible phenolic acids in Sorghum bicolor could be responsible for the delay in germination of weed species. Similarly, Anjum et al. (2005) reported that chlorogenic and isochlorogenic acids in sunflower may be attributed to the inhibition 
and the delay in time to germination. In crops, weed competition time to emergence is an important factor; therefore, the findings of the current study are valuable for the weed scientists to further explore the possibility of such plants water extracts for delaying the germination time in weed species and enabling the crops to capture the space prior to weed germination.

\section{Shoot length (cm plant $\left.{ }^{-1}\right)$}

The statistical analysis of the data showed that the extracts had significant effect on shoot length ( $\left.\mathrm{cm} \mathrm{plant}^{-1}\right)$ of test species (Table 5). The data recorded for maize showed that maximum shoot length $\left(38.46 \mathrm{~cm}\right.$ plant $\left.^{-1}\right)$ was recorded in control (distilled water), while minimum (29.99 $\mathrm{cm}$ plant $^{-1}$ ) was recorded in sunflower + sorghum + parthenium (WEs) treatment which was statistically at par with herbicide (atrazine) treatment. Furthermore, maximum shoot length of Trianthema $\left(6.20 \mathrm{~cm} \mathrm{plant}^{-1}\right)$ was recorded in control (distilled water) treatment, while the minimum $\left(3.55 \mathrm{~cm} \mathrm{plant}^{-1}\right)$ was recorded in herbicide (atrazine) treatment. Data recorded for the Lolium showed the maximum shoot length (16.96 $\mathrm{cm}$ plant $\left.^{-1}\right)$ in control (distilled water) treatment while the minimum $\left(9.45 \mathrm{~cm} \mathrm{plant}^{-1}\right)$ was recorded in herbicide (atrazine) treatment which was statistically at par with sunflower + sorghum + parthenium (WEs) treatment. Among the species means, maximum shoot length $\left(32.36 \mathrm{~cm} \mathrm{plant}^{-1}\right)$ was recorded for maize followed by Lolium with $\left(11.76 \mathrm{~cm}_{\text {plant }}{ }^{-1}\right)$ whereas the lowest shoot length $\left(4.5 \mathrm{~cm}\right.$ plant $\left.{ }^{-1}\right)$ was recorded for Trianthema. Among the treatment means maximum shoot length (20.54 $\mathrm{cm}$ plant $\left.^{-1}\right)$ was recorded in control (distilled water) treatment while minimum $\left(14.46 \mathrm{~cm} \mathrm{plant}^{-1}\right)$ was recorded in herbicide (atrazine) treatment which was statistically at par with sunflower + sorghum + parthenium (WEs) treatment.

Table 5. Allelopathic effect of different plant water extracts applied sole and mixed on shoot length ( $\mathrm{cm}$ ) of Z. mays and its associated weeds under laboratory conditions (pots study)

\begin{tabular}{|c|c|c|c|c|}
\hline \multirow{2}{*}{ Treatments $(1: 10 \mathrm{w} / \mathrm{v})$} & \multicolumn{3}{|c|}{ Species tested } & \multirow{2}{*}{$\begin{array}{c}\text { Extracts } \\
\text { means }\end{array}$} \\
\hline & Z. mays & T. partulacastrum & L. rigidum & \\
\hline Sorghum & $35.51 \mathrm{~b}$ & $5.04 \mathrm{n}$ & $12.12 \mathrm{i}$ & $17.57 \mathrm{~b}$ \\
\hline Sunflower & $31.85 \mathrm{~d}$ & $4.95 \mathrm{n}$ & $12.94 \mathrm{~h}$ & $16.58 \mathrm{c}$ \\
\hline Parthenium & $32.48 \mathrm{c}$ & $4.95 n$ & $12.10 \mathrm{i}$ & $16.51 \mathrm{c}$ \\
\hline Sorghum + Sunflower (50\% ea.) & $31.39 \mathrm{~d}$ & $4.16 \mathrm{o}$ & $10.28 \mathrm{k}$ & $15.28 \mathrm{~d}$ \\
\hline Sorghum + Parthenium (50\% ea.) & $30.58 \mathrm{e}$ & 3.99op & $11.20 \mathrm{j}$ & $15.26 \mathrm{~d}$ \\
\hline Sunflower + Parthenium (50\% ea.) & $30.68 \mathrm{e}$ & $4.00 \mathrm{op}$ & $11.11 \mathrm{j}$ & $15.26 \mathrm{~d}$ \\
\hline Sunflower + Sorghum + Parthenium (33.3\%ea.) & $29.99 \mathrm{f}$ & $3.71 \mathrm{op}$ & 9.701 & $14.47 \mathrm{e}$ \\
\hline Atrazine (herbicide) & $30.37 \mathrm{ef}$ & $3.55 \mathrm{p}$ & 9.451 & $14.46 \mathrm{e}$ \\
\hline Control (distilled water) & $38.46 \mathrm{a}$ & $6.20 \mathrm{~m}$ & $16.96 \mathrm{~g}$ & $20.54 \mathrm{a}$ \\
\hline Test species means & $32.37 \mathrm{a}$ & $4.5 \mathrm{c}$ & $11.76 b$ & \\
\hline
\end{tabular}

$\mathrm{LD}_{0.05}$ for extracts $=0.32$, for test species $=0.18$ and for interaction $=0.55$. The means followed by the same letter ( $\mathrm{s}$ ) in the respective category do not differ significantly from one another at $\mathrm{P} \leq 0.05$ according to $\mathrm{LSD}_{0.05}$ test

Our results are also in close conformity with the findings of Javaid et al. (2009) who found that water extracts of Withania somnifera and Datura alba have bioactive compounds responsible for the inhibition of root and shoot growth of Rumex crispus. 
The presence of p-coumaric, vanillic, syringic, and ferulic acids in allelopathic plants may inhibit the shoot growth of the tested species. Our results are further similar to that of Turk and Tawah, 2002, who stated that allelopathic plants water extracts were more promising on radicle growth, as radicle emerges earlier and comes in contact with phytochemicals. Based on the current study it is suggested to exploit the utilization of these extracts for sustainable weed management in maize under field condition if infested with Trianthema portulacastrum (horse purslane) and Lolium rigidum.

\section{Dry biomass ( plant $^{-1}$ )}

The statistical analysis of the data showed that the extracts had significant effect on dry biomass $\left(\mathrm{g} \mathrm{plant}^{-1}\right)$ of the tested species (Table 6$)$. The data recorded for maize showed the maximum dry biomass $\left(0.2585 \mathrm{~g} \mathrm{plant}^{-1}\right)$ in control (distilled water) treatment, whereas the minimum $\left(0.1895 \mathrm{~g} \mathrm{plant}^{-1}\right)$ biomass was recorded in herbicide (atrazine) treatment. Furthermore, the data recorded for Trianthema showed maximum dry biomass $\left(0.0707 \mathrm{~g} \mathrm{\text {plant } ^ { - 1 }}\right)$ in control (distilled water), while the minimum $\left(0.0163 \mathrm{~g} \mathrm{plant}^{-1}\right)$ was recorded in herbicide (atrazine) treatment. Similarly, data recorded for the Lolium dry biomass, the maximum value (3.04 $\left.\mathrm{g} \mathrm{plant}^{-1}\right)$ was recorded in control (distilled water) treatment, while the minimum (1.66 g plant $\left.{ }^{-1}\right)$ was recorded in herbicide (atrazine) treatment. Among the species means maximum dry biomass ( $\left.2.14 \mathrm{~g} \mathrm{plant}^{-1}\right)$ was recorded for Lolium followed by maize with $\left(0.2126 \mathrm{~g} \mathrm{plant}^{-1}\right)$, whereas minimum value $\left(0.038 \mathrm{~g} \mathrm{plant}^{-1}\right)$ was recorded for Trianthema. Among the treatment means maximum dry biomass $\left(1.12 \mathrm{~g} \mathrm{plant}^{-1}\right)$ was recorded in control (distilled water) treatment, whereas the minimum (1.62 $\left.\mathrm{g} \mathrm{plant}^{-1}\right)$ was recorded in herbicide (atrazine) treatment. Among the tested species maize showed tolerance to various allelopathic water extracts, whereas Trianthema and Lolium species were found more susceptible to herbicide treatment (atrazine) followed by sunflower + sorghum + parthenium (WEs) treatment.

Table 6. Allelopathic effect of different plants water extracts applied isolated and in mixture on dry biomass $(g)$ of $Z$. mays, and its associated weeds under laboratory conditions (pots study)

\begin{tabular}{c|c|c|c|c}
\hline & \multicolumn{3}{|c|}{ Species tested } & \\
\hline Treatments (1:10 w/v) & Z. mays & T. partulacastrum & L. rigidum & $\begin{array}{c}\text { Extracts } \\
\text { means }\end{array}$ \\
\hline Sorghum & $0.2175 \mathrm{~b}$ & $0.0508 \mathrm{ij}$ & $2.32 \mathrm{~b}$ & $0.86 \mathrm{~b}$ \\
Sunflower & $0.2157 \mathrm{~b}$ & $0.0482 \mathrm{ij}$ & $2.33 \mathrm{~b}$ & $0.86 \mathrm{~b}$ \\
Parthenium & $0.2148 \mathrm{~h}$ & $0.0440 \mathrm{ij}$ & $2.30 \mathrm{~b}$ & $0.85 \mathrm{~b}$ \\
Sorghum + Sunflower (50\% ea.) & $0.2048 \mathrm{bd}$ & $0.0295 \mathrm{j}$ & $1.99 \mathrm{c}$ & $0.74 \mathrm{c}$ \\
Sorghum + Parthenium (50\% ea.) & $0.2063 \mathrm{bc}$ & $0.0315 \mathrm{j}$ & $1.94 \mathrm{~d}$ & $0.73 \mathrm{c}$ \\
Sunflower + Parthenium (50\% ea.) & $0.2092 \mathrm{bc}$ & $0.0283 \mathrm{j}$ & $1.94 \mathrm{~d}$ & $0.73 \mathrm{c}$ \\
Sunflower + Sorghum + Parthenium (33.3\%ea.) & $0.1968 \mathrm{~cd}$ & $0.0227 \mathrm{j}$ & $1.80 \mathrm{e}$ & $0.67 \mathrm{~d}$ \\
Atrazine (herbicide) & $0.1895 \mathrm{~h}$ & $0.0163 \mathrm{j}$ & $1.66 \mathrm{f}$ & $0.62 \mathrm{e}$ \\
Control (distilled water) & $0.2585 \mathrm{~g}$ & $0.0707 \mathrm{i}$ & $3.04 \mathrm{a}$ & $1.12 \mathrm{a}$ \\
\hline Test species means & $0.213 \mathrm{~b}$ & $0.038 \mathrm{a}$ & $2.146 \mathrm{c}$ & \\
\hline
\end{tabular}

$\mathrm{LSD}_{0.05}$ for extracts $=0.022$, for test species $=0.013$ and interaction $=0.039$ and for each effect, values with the same letter ( $\mathrm{s}$ ) in a column do not differ significantly from one another at $\mathrm{P} \leq 0.05$ according to LSD test 
The tolerance of maize seeds and sensitivity of weed seeds to these extracts are interesting findings which could be further explored as a tool for sustainable weed management strategies. The presence of sorgoleone, phenolics, p-coumaric, vanillic, syringic, and ferulic acids in allelopathic plants may inhibit the fresh and dry biomass $\left(\mathrm{g} \mathrm{plant}^{-1}\right)$ of the tested species by inhibiting the electron transport in both photosynthesis and respiration, resulting in the reduction in chlorophyll content, and reduction in chlorophyll accumulation. It is concluded from the current study that allelopathic plants water extracts could decrease dry biomass $\left(\mathrm{g} \mathrm{plant}^{-1}\right)$ of weeds, which is a positive indicator of such studies, although synthetic herbicides are cheaper and effective than allelochemicals, but still it seems that allelochemicals could be used in developing countries as an ecological and ecofriendly weed management tool. It is suggested to study the active ingredient of allelochemicals to understand their behaviors and plant responses to their applications.

\section{General discussion}

In the laboratory bioassays, it is observed that among the tested species maize seeds showed tolerance whereas Trienthema followed by Lolium showed more sensitivity against synthetic herbicides and other applied allelopathic water extracts. In the light of the present findings of the current study, the tolerance of maize seeds and sensitivity of weed seeds against allelopathins is a good indicator that could be explored further for the commercial use of the selective weed management strategy. Allelopathic plants/weed water extracts applied in combination had more inhibitory effect than their sole application on seed germination, time to germination, shoot length and dry biomass of the tested species. The similar trends for all the studied parameters are confirmatory to the previous findings of Einhellig (1995) and Weston and Duke (2003), who reported that application of various allelopathic plants water extracts in mutual combination had more pronounced inhibitory effect as compared to their sole applications. Likewise, Khanh et al. (2005) also illustrated that a mixture of allelochemicals may help to retard the germination and seedling growth of weed species. The more inhibitory effect in combined extracts could be due to synergistic action of various allelochemicals present in the plant species, however data recorded for shoot length $(\mathrm{cm})$ and dry biomass $(\mathrm{g})$ showed that inhibitory effect of synthetic herbicide had slightly more effect than combined application of extracts, but pollution, herbicide resistance development and harming the quality of product encourages to opt for the allelopathins. Our results are also in line with the work of Cheema and Khaliq (2000) and Hassan et al. (2018), who observed the inhibitory effect of allelopathic crops/weed extracts on weeds and concluded worth to be exploited for weed management in different crops.

\section{Conclusion}

It is concluded from the current study that all tested allelopathic plants species viz., sorghum, sunflower and parthenium have phytotoxic effect against the two studied weeds of maize. They have water soluble allelochemicals which could inhibit the germination\% and growth parameters of weeds. Among all the treatments, Sorghum + Sunflower + Parthenium (WEs) significantly minimized the growth of the tested species almost comparable to the synthetic herbicide (atrazine). A positive indicator during the study has been that maize (Zea mays L.) showed more tolerance against the tested extracts thus, offering a window for selective control of weeds in maize crop 
consequently averting the reliance on the synthetic herbicides. Another prospect of this study is the combined use of the tested species emerged as synergistic for the effective control of weeds as compared to their sole application. It is thus, recommended that the combined extracts of the tested plants may be utilized for sustainable weed management in maize crop for environmental safety and sustainable maize production. Water extract of sorghum + sunflower + parthenium @ 33.3+33.3+33.3 g/L in mutual combination may be recommended for sustainable weed management in maize.

Acknowledgements. This study is a part of a $\mathrm{PhD}$ dissertation, which was submitted by the senior author to the University of Haripur Pakistan, for the award of degree. Authors are very thankful to the Higher Education Commission (HEC) Pakistan for full financial assistance under the Project HEC Indigenous 5000 PhD Fellowship Program Phase-II, Batch-I.

\section{REFERENCES}

[1] Adkins, S. W., Sowerby, M. S. (1996): Allelopathic potential of the weed, Parthenium hysterophorus L., in Australia. - Plant Protection Quarterly 11(1): 20-23.

[2] An, M., Pratley, E., Haig, T. (1998): Allelopathy: from Concept to Reality. Environmental and Analytical Laboratories and Farrer Center for Conservation Farming, Charles Sturt University, Wagga NSW.

[3] Anjum, T., Stevenson, P., Hall, D., Bajwa, R. (2005): Allelopathic potential of Helianthus annuus L.(sunflower) as natural herbicide. - Proceedings of the 4th World Congress on Allelopathy: Establishing the Scientific Base, Wagga, Australia, 2005 August, pp. 21-26.

[4] Balyan, R. S., Bhan, V. M. (1989): Competing ability of maize, pearlmillet, mungbean and cowpea with carpetweed under different weed management practices. - Crop Research (Hisar) 2(2): 147-153.

[5] Batish, D. R., Tung, P., Singh, H. P., Kohli, R. K. (2002b): Phytotoxicity of sunflower residues against some summer season crops. - Journal of Agronomy and Crop Science 188(1): 19-24.

[6] Belz, R. G. (2008): Stimulation versus inhibition-bioactivity of parthenin, a phytochemical from Parthenium hysterophorus L. - Dose-Response 6(1): 80-96.

[7] Belz, R. G. (2016): Investigating a potential auxin-related mode of hormetic/inhibitory action of the phytotoxin parthenin. - Journal of Chemical Ecology 42(1): 71-83.

[8] Belz, R. G., Reinhardt, C. F., Foxcroft, L. C., Hurle, K. (2007): Residue allelopathy in Parthenium hysterophorus L.-Does parthenin play a leading role? - Crop Protection 26(3): 237-245.

[9] Cheema, Z. A., Khaliq, A. (2000): Use of sorghum allelopathic properties to control weeds in irrigated wheat in a semiarid region of Punjab. - Agriculture, Ecosystems \& Environment 79(2-3): 105-112.

[10] Das, B., Das, R. (1995): Chemical investigation in Parthenium hysterophorus L. - an allelopathic plant. - Allelopathy J 2: 99-104.

[11] Dogan, M. N., Ünay, A., Boz, Ö., Albay, F. (2004): Determination of optimum weed control timing in maize (Zea mays L.). - Turkish Journal of Agriculture and Forestry 28(5): 349-354.

[12] Einhellig, F. A. (1995): Mechanism of Action of Allelochemicals in Allelopathy. - In: Inderjit, K. M. M. et al. (eds.) Allelopathy. ACS, Washington, pp 96-116. DOI: 10.1021/bk-1995-0582.ch007.

[13] Guenzi, W. D., McCalla, T. M. (1966): Phenolic acids in oats, wheat, sorghum, and corn residues and their phytotoxicity. - Agronomy Journal 58(3): 303-304.

[14] Gupta, P. K. (2004): Pesticide exposure - Indian scene. - Toxicology 198(1-3): 83-90. 
[15] Heap, I. (2020): The International Survey of Herbicide Resistant Weeds. www.weedscience.org (accessed on April 2, 2020).

[16] Heap, I., Duke, S. O. (2018): Overview of glyphosate-resistant weeds worldwide. - Pest Manag. Sci. 74(5): 1040-1049.

[17] Iqbal, J., Cheema, Z. A., Mushtaq, M. N. (2009): Allelopathic crop water extracts reduce the herbicide dose for weed control in cotton (Gossypium hirsutum). - International Journal of Agriculture and Biology 11(4): 360-366.

[18] Jabran, K. (2018): Tank mixing of allelopathic crop water extracts with pendimethalin helps in the management of weeds in canola (Brassica napus) field. - International Journal of Agriculture and Biology 10(3): 293-296.

[19] Jabran, K., Mahajan, G., Sardana, V., Chauhan, B. S. (2015): Allelopathy for weed control in agricultural systems. - Crop Protection 72: 57-65.

[20] Khan, M. B., Ahmad, M., Hussain, M., Jabran, K., Farooq, S., Waqas-Ul-Haq, M. (2012): Allelopathic plant water extracts tank mixed with reduced doses of atrazine efficiently control Trianthema portulacastrum in L. Zea mays. - Journal of Animal and Plant Sciences 22(2): 339-346.

[21] Khan, T. D., Chung, M. I., Xuan, T. D., Tawata, S. (2005): The exploitation of crop allelopathy in sustainable agricultural production. - Journal of Agronomy and Crop Science 191(3): 172-184.

[22] Leather, G. R. (1987): Weed control using allelopathic sunflowers and herbicide. - Plant and Soil 98(1): 17-23.

[23] Leather, G. R. (1983): Sunflowers (Helianthus annuus) are allelopathic to weeds. - Weed Science 31(1): 37-42.

[24] NewGenFartmer Maize + Soybean (2020): Top 10 worst weeds in corn and soybean. https://www.farmprogress.com/crop-protection/top-10-worst-weeds-corn-and-soybeans.

[25] Sohaib, M., Zaheer-ud-din, K., Cheema, T. A. (2009): Distribution of weeds in wheat, maize and potato fields of Tehsil Gojra, District Toba Tek Singh, Pakistan. - Pakistan Journal of Weed Science Research 15(1): 91-103.

[26] Turk, M. A., Tawaha, A. M. (2002): Inhibitory effects of aqueous extracts of barley on germination and growth of lentil. - Pakistan Journal of Agronomy 1: 28-30.

[27] Usman, A., Elemo, K. A., Bala, A., Umar, A. (2001): Effect of weed interference and nitrogen on yields of a maize/rice intercrop. - International Journal of Pest Management 47(4): 241-246.

[28] University of Pretoria (2020): Important Weeds in Maize. https://www.up.ac.za/sahri/article/1810372/important-weeds-in-maize. Accessed on April 7, 2020.

[29] Weston, L. A., Duke, S. O. (2003): Weed and crop allelopathy. - Critical Reviews in Plant Sciences 22(3-4): 367-389. 